\title{
THE IMPACT OF CEMPO FINAL WASTE DISPOSAL ON SKIN DISEASE IN MOJOSONGO COMMUNITY, SURAKARTA
}

\author{
Tri Yuniarti, Titik Anggraeni \\ Academy of Nursing Mamba’Ul Ulum, Surakarta, Central Java
}

\begin{abstract}
Background: Garbage has the potential to cause pollution and health problems. Pollution can occur in the air as a result of waste decomposition, can also contaminate water and soil caused by leakage (liquid waste) resulting in various skin diseases. The skin disease are caused by several types of pathogenic microorganism that live and breed in the waste. This study aimed to determine the impact of long residence adjacent to sanitary landfill, distance to landfill, and skin contact with garbage on skin disease symptoms at Putri Cempo final waste disposal, Mojosongo, Surakarta.

Subjects and Method: This was an analytic observational study using cross sectional design. This study was conducted in Putri Cempo final waste disposal, Mojosongo, Surakarta, Central Java. A sample of 102 residents living near the Putri Cempo waste disposal were selected for this study. The dependent variable was symptoms of skin disease. The independent variables were duration of residence near the sanitary landfill, house distance to landfill, and skin contact with garbage. The data were collected by questionnaire and analyzed using multiple logistic regression.
\end{abstract}

Results: Residence near the sanitary landfill near $\geq 3$ years $(\mathrm{OR}=6.00 ; 95 \%$ $\mathrm{CI}=1.97$ to $18.20 ; \mathrm{p}=0.002)$ and house distance to landfill $<1 \mathrm{~km}(\mathrm{OR}=9.50$; $95 \% \mathrm{CI}=3.10$ to $28.80 ; \mathrm{p}=0.001$ ) increased the risk of skin disease symptoms. Indirect contact with waste $(\mathrm{OR}=0.68 ; 95 \% \mathrm{CI}=0.10$ to $2.90 ; \mathrm{p}=$ 0.605) was associated with decreased skin disease symptoms, but it was statistically insignificant.

Conclusion: Residence near the sanitary landfill near $\geq 3$ years and house distance to landfill $<1 \mathrm{~km}$ increase the risk of skin disease symptoms.

Keywords: skin disease, symptomp, waste disposal, sanitary landfill, residence

Correspondence: Tri Yuniarti. Academy of Nursing Mamba’Ul Ulum, Surakarta, Central Java. 